\title{
PENTINGNYA KESADARAN ANTARBUDAYA DAN KOMPETENSI KOMUNIKASI ANTARBUDAYA DALAM DUNIA KERJA GLOBAL
}

\author{
Amia Luthfia \\ Marketing Communication Department, Faculty of Economic and Communication, BINUS University \\ Jln. K.H. Syahdan No.9, Palmerah, Jakarta Barat 11480 \\ amialuthfia@gmail.com
}

\begin{abstract}
In this global era, communication, interaction and intercultural encounters happen every second. Technology expands the ability of people throughout the world to connect to each other for vacation or for business purpose. Intercultural communication skills will be critical necessity. The ability to work in multicultural workforce and interact with people from other cultures, often in other languages, is inherent to the success of a multinational business. Effective global enterprise communication skills are the backbone that supports the transaction of business around the world. This paper highlights the importance of intercultural awareness and the need for intercultural communication competence training for all local and multinational companies. Therefore, intercultural cooperation and synergy become an important aspect in this era. Companies that have intercultural competence will be able to succeed and sustain success in global business.
\end{abstract}

Keywords: intercultural communication, intercultural awareness, intercultural competency, global workplace, multinational company

\begin{abstract}
ABSTRAK
Pertemuan, interaksi, dan komunikasi antarorang yang berbeda latar belakang budaya terjadi setiap detik pada era ini. Mobilitas orang makin mudah dan sering, tidak hanya untuk berlibur tetapi juga untuk bekerja di negara lain dan berbisnis dengan mitra asing. Sering kali kegagalan transaksi bisnis terjadi hanya karena kegagalan dalam berkomunikasi antarbudaya. Artikel ini menyoroti pentingnya kesadaran antarbudaya dan perlunya pelatihan kompetensi komunikasi antarbudaya bagi semua pimpinan dan perusahaan lokal dan multinasional. Oleh karena itu, kerja sama dan sinergi antarbudaya tidak dapat dihindari dan menjadi aspek penting pada era global ini. Perusahaan yang memiliki kompetensi antarbudaya akan mampu sukses dan mempertahankan kesuksesan dalam bisnis global.
\end{abstract}

Kata kunci: komunikasi antarbudaya, kesadaran antarbudaya, kompetensi antarbudaya, dunia kerja global, perusahaan multinasional 


\section{PENDAHULUAN}

Globalisasi telah memberikan efek pada budaya dan perilaku manusia dalam berbagai setting dan konteks. Interaksi manusia dari berbagai belahan dunia saat ini sangatlah mudah dengan kemajuan teknologi informasi yang sangat pesat. Setiap detik selama 24 jam setiap hari manusia berkomunikasi dan berinteraksi dengan manusia lain dari berbagai belahan dunia lain melalui media atau pertemuan langsung. Pertemuan antarbudaya makin mudah dan sering serta makin banyak orang yang bepergian ke negara lain, apakah itu untuk urusan bisnis, pekerjaan, belajar atau liburan.

Pada era global dan era perdagangan bebas ini makin banyak perusahaan multinasional di berbagai negara, juga perusahaan-perusahaan lokal yang mengembangkan bisnis ke negara-negara lain. Konsekuensinya adalah makin banyaknya keberadaan pekerja dan profesional asing di suatu negara atau orang bekerja di negara lain. Jumlah tenaga kerja asing di berbagai perusahaan lokal maupun multinasional makin hari semakin meningkat. Menurut Yoshida (2002), Managing Director Sumitomo Chemical Asia Pte. Ltd, strategi perusahaan untuk merambah bisnis global bukanlah lagi sebuah pilihan namun sebuah keharusan untuk dapat terus berlangsung hidup. Perusahaan terusmenerus membutuhkan kapital, sumber daya manusia, jasa, barang-barang, dan informasi untuk dapat tetap tumbuh.

Di Indonesia sendiri, pada 2012 jumlah tenaga kerja asing adalah sebanyak 57.329 orang. Jumlah terbanyak berasal dari RRC sebanyak 12.835 orang, kemudian disusul oleh Jepang, Korea Selatan, India, dan Malaysia. Tenaga kerja asing yang berasal dari luar Asia, sebagian besar berasal dari Australia, USA, Inggris, dan Prancis yang masing-masing sekitar 2000 orang. Jumlah ini menurun drastis dibandingkan jumlah pekerja asing pada 2011 yang mencapai 118.000 orang (Kementerian Tenaga Kerja dan Transmigasi Republik Indonesia, 2013). Sedangkan warga negara Indonesia yang berada di luar negeri mencapai 4 juta orang, apakah sebagai pekerja profesional, pelajar, TKI, TKW, atau permanent residence. WNI ini paling banyak berada di Malaysia, Singapura, Arab Saudi, Korea, AS, Inggris, Jerman, dan Australia (Gustaman, 2012).

Tenaga kerja asing yang berada di Indonesia sebagian besar berasal dari perusahaan PMA (Penanaman Modal Asing). Ada juga yang bekerja pada perusahaan-perusahaan asing yang mengakuisisi atau merger atau berafiliasi dengan perusahaan Indonesia. Keberadaan tenaga kerja asing di perusahaan asing atau perusahaan lokal bukan tanpa persoalan. Konflik antara buruh dengan pengusaha atau manajer asing beberapa kali terjadi. Demo buruh sangat kerap terjadi yang sampai mengakibatkan beberapa perusahaan asing pull out dari Indonesia karena merasa tidak aman.

Kecemburuan sosial, kesenjangan gaji dan fasilitas adalah salah satu akar masalah walaupun awal munculnya konflik terbuka sering kali karena masalah komunikasi antarbudaya. Salah satu contohnya adalah kasus pada PT Drydock World Graha di Batam. Berdasarkan berita di Kompas.com, konflik bermula dari umpatan seorang supervisor asal India yang mengatakan pekerja Indonesia "stupid". Umpatan itu spontan menyulut emosi pekerja Indonesia lainnya. Perkelahian pun tak terhindarkan antara pekerja asing berdarah India dengan pekerja Indonesia —yang menurut mereka sudah sering mendapat hinaan serupa. "Kalau topi ini bisa ngomong, dia akan ngomong kalau tiap hari kita ini dimaki-maki bodoh dan sebutan lainnya," ujar seorang karyawan Indonesia. Dampak dari umpatan ini adalah demonstrasi buruh dan aksi pembakaran terhadap berbagai fasilitas perusahaan. Puluhan tenaga kerja asing terpaksa dievakuasi dari Batam (Kompas).

Konflik antarbudaya tidak bisa dianggap sepele. Berkata dan bertindak kasar bisa jadi merupakan hal biasa di suatu budaya, tetapi merupakan hal yang luar biasa dan penghinaan di budaya yang lain. Kegagalan komunikasi sehari-hari, kesalahpahaman karena faktor perbedaan bahasa, perbedaan latar belakang budaya, sikap perilaku eksklusif karena merasa ekspatriat, dan sikap-sikap 
lain yang tidak sesuai dengan latar budaya lokal dapat menimbulkan prasangka serta sangat mungkin diakhiri dengan konflik terbuka yang berakibat fatal.

Dalam ranah global sendiri, dunia mengarah menjadi multicultural society, yang di dalamnya setiap orang bisa saja berasal dari beberapa ras yang berbeda dan hidup pada beberapa konteks budaya (Samovar, Porter, \& McDaniel, 2010). Contohnya saja Presiden Barack Obama; ia lahir di Hawaii yang penduduk aslinya bukanlah orang kulit putih, ayahnya berasal dari Kenya, ibunya dari ras kulit putih, pernah tinggal di Indonesia bersama ayah tiri orang Indonesia, kemudian menetap di Hawaii bersama neneknya yang kulit putih.

Untuk konteks bisnis, banyak perubahan terjadi terutama sejak pesatnya perkembangan teknologi informasi. Transaksi bisnis dapat dilakukan dalam hitungan menit; pertukaran informasi dari berbagai belahan dunia terjadi setiap detik. Profesional dan pengusaha bisa kapan saja melakukan kontak dan melakukan perjalanan bisnis ke berbagai negara. Sayangnya, kemampuan dan keterampilan berkomunikasi antarbudaya untuk kelancaran hubungan dan bisnis tidak semua disadari oleh para pelaku bisnis. Hal itu ditambah lagi dengan sangat minimnya pelatihan komunikasi antarbudaya untuk mengatasi beragam hambatan antarbudaya. Banyak kegagalan transaksi bisnis terjadi hanya karena kegagalan dalam berkomunikasi antarbudaya.

Pelatihan untuk meningkatkan kompetensi berkomunikasi antarbudaya dan untuk meningkatkan kesadaran antarbudaya menjadi suatu keharusan bagi perusahaan global maupun lokal. Kurangnya kesadaran antarbudaya dan kurang cakapnya dalam berkomunikasi antarbudaya sering kali menciptakan kesalahpahaman. Kesalahpahaman ini dapat menimbulkan rasa tersinggung dan ketidakpercayaan dari kedua belah pihak. Bahkan kesalahpahaman dapat terjadi hanya karena perbedaan dalam gaya berkomunikasi (Yoshida, 2002). Melalui tulisan ini, penelitian bertujuan untuk menunjukkan pentingnya kesadaran antarbudaya dan kemampuan berkomunikasi antarbudaya dengan efektif di era global.

\section{METODE}

Metode penulisan artikel ini adalah studi pustaka. Data dan informasi diperoleh dari data sekunder yang berasal dari buku dan referensi yang berkaitan dengan tema artikel. Sumber utama tulisan ini adalah berbagai hasil penelitian yang telah dilakukan tertuang dalam berbagai jurnal dan berbagai textbook komunikasi antarbudaya.

\section{HASIL DAN PEMBAHASAN}

\section{Memahami Keanekaragaman Budaya dan Kesadaran Antarbudaya}

Perbedaan dan keanekaragaman adalah sesuatu yang alamiah. Setiap orang, setiap bangsa memiliki keunikan sendiri-sendiri. Walaupun dunia terasa seperti makin sempit dan makin pudar, batas-batas negara karena kemajuan teknologi, perbedaan dan keanekaragaman akan tetap ada. Banyak yang berpendapat globalisasi dapat menyeragamkan budaya-budaya yang ada dan tidak perlu lagi terlalu mengkhawatirkan perbedaan-perbedaan budaya yang ada, tetapi penulis yakin perbedaan dan keanekaragaman budaya pasti akan tetap ada. Perbedaan dan keanekaragaman justru menambah semaraknya kehidupan serta merupakan kekayaan bangsa. 
Siapapun yang berada dalam konteks bisnis internasional, bekerja pada perusahaan asing atau menjadi ekspatriat di suatu negara, ketika berinteraksi dengan orang asing pasti pernah mengalami tatapan mata yang menyiratkan ketidakpahaman, senyuman yang dipaksakan, gumaman komentar dalam bahasa yang tidak jelas akibat tidak dipahaminya kata-kata yang diucapkan. Sebaliknya terkadang tanpa disadari, kita sendiri pernah membuat orang lain bingung dengan bahasa tubuh, ekspresi wajah, dan aksen berbicara kita. Orang-orang dengan budaya yang berbeda memproses informasi dengan cara yang berbeda, menilai perlakuan secara berbeda dan mengukur konsep waktu dan ruang dalam pola yang berbeda pula. Ketidakpekaan atas perbedaan budaya bisa menjelma menjadi masalah bisnis yang serius (Mitchell, 2008).

Satu contoh dikisahkan oleh Mitchell (2008) tentang masalah bisnis yang serius yang dialami oleh Disneyland akibat ketidakpekaan budaya. Setelah sukses membuka Disneyland di Jepang, Disneyland akan membuat taman bermain ini di Prancis. Oleh karena merasa sudah membuat keberhasilan di Jepang - yang memiliki budaya yang sangat berbeda - Disneyland merasa tidak perlu mengubah sistem yang sudah dianggap berhasil untuk disesuaikan dengan orang Eropa. Masalah terjadi sejak awal pembelian lahan 1.950 hektar. Tanah yang dibeli adalah lahan pertanian utama dengan harga di bawah harga pasar. Para keluarga petani Prancis yang telah berabad-abad mengelola tanah tersebut marah dan menentang. Surat kabar Prancis mencela pengusaha Amerika dengan tulisantulisan yang penuh kemarahan dan hinaan bahwa Disneyland telah menyepelekan ikatan petani Prancis dengan tanah leluhurnya. Selanjutnya Disneyland makin menyinggung perasaaan masyarakat Prancis dengan menggunakan pengacara untuk bernegosiasi kontrak-kontrak yang akan dilakukan. Di Prancis pengacara adalah alat negosiasi terakhir. Penggunaan pengacara menunjukkan ketidakpercayaan dan penolakan terhadap cara Prancis. Seharusnya cukup para eksekutif Disneyland saja yang bernegosiasi. Masalah makin rumit karena ketidakpedulian Disneyland akan kultur Eropa dan norma kerja Prancis. Disneyland menuntut karyawan-karyawannya berpenampilan gaya Amerika. Akibatnya, staf dan serikat buruh memberontak dan menuntut model pakaian sehari-hari Prancis. Moral kerja merosot. Selain hal-hal tersebut, banyak sekali detail budaya yang diabaikan Disneyland di Prancis. Biaya akibat ketidakpekaan perusahaan terhadap budaya menghabiskan uang dan goodwill yang sangat besar.

Ketidakpekaan dan pengabaian detail budaya juga banyak dilakukan oleh para pelaku bisnis dan manajer global. Mereka cenderung menyamaratakan cara dan gaya untuk diterapkan pada budaya yang berbeda. Komentar-komentar seperti "Cara ini berhasil di negara saya, jadi dengan cara ini akan berhasil di mana pun," "Saya tahu bagaimana menjual/membuat/mengelola bisnis ini di mana pun," "Produk saya adalah yang terbaik, saya tidak perlu khawatir dengan perbedaan budaya," sering kali terdengar (Beamer \& Varner, 2008).

Sikap menganggap bahwa budaya sendiri adalah budaya yang terbaik dan budaya-budaya lain seharusnya mengikuti tata cara budaya sendiri dan dinilai berdasarkan standar budaya sendiri adalah sikap yang harus dihindari ketika berinteraksi dengan orang dari budaya yang berbeda. Sikap ini adalah bentuk dari etnosentrisme negatif (Samovar, Porter, \& McDaniel, 2010). Jika seorang cenderung bersikap etnosentrisme negatif, hal itu akan menghambat keberhasilan dalam berkomunikasi antarbudaya.

Setiap budaya memiliki keunikan dan karakteristik tersendiri, "berbeda bahasa, berbeda dunia" (Lewis, 2005). Lewis (2005) menunjukkan beberapa perbedaan unik dari beberapa bangsa, seperti:

"Bagi orang Jerman dan Finlandia, kebenaran adalah kebenaran. Di Jepang dan Inggris, kebenaran yang baik apabila kebenaran itu tidak mengganggu keselarasan. Di Cina tidak ada kebenaran mutlak. Di Italia, kebenaran bisa dirundingkan.” 


\begin{abstract}
"Orang Jepang tidak menyukai jabat tangan, tapi lebih menyukai membungkuk ketika menghormat orang lain dan tidak membersihkan hidung di muka umum. Orang Brazil terbiasa untuk tidak antre ketika naik bis, lebih menyukai sepatu warna coklat daripada hitam, dan datang terlambat dua jam pada pesta koktail. Orang Yunani menatap bola mata anda, menganggukkan kepalanya berarti 'tidak', dan ada kalanya membanting piring di restoran.”
\end{abstract}

Yoshida (2002) juga menyampaikan kisah tentang pertemuan bisnis antara delegasi Amerika Serikat dengan pejabat tinggi Jepang. Ia menyebutkan masalah yang dihadapinya saat itu adalah "perception gap". Diceritakannya, setelah delegasi Amerika selesai bertemu dengan pejabat tinggi Jepang, salah satu anggota delegasi bercerita pada seorang teman baiknya yang berkebangsaan Jepang tentang impresinya terhadap pertemuan itu.

"Delegasi Jepang menerima kami dengan sangat baik dan terlihat sangat menyimak apa yang kami katakan. Tapi setelah pertemuan itu, semua anggota delegasi kami menyatakan tidak dapat memahami dengan jelas hal-hal apa saja yang delegasi Jepang ingin lakukan. Kami juga merasakan suasana yang 'dingin' selama pertemuan dan akhirnya kami merasakan bahwa orang Jepang lebih sombong daripada sebelumnya."

Keesokan paginya, surat kabar Tokyo mengutip pernyataan salah satu pejabat tinggi Jepang yang ikut serta dalam pertemuan, "kami sangat menghargai pertemuan yang telah dilakukan, kami berusaha sebagai pendengar yang baik daripada memaksakan pandangan kami pada mereka dan kami merasa delegasi Amerika menghargainya."

Berbeda dengan persepsi delegasi Amerika, orang Jepang menganggap suasana 'dingin' yang dirasakan adalah sikap yang tepat dan baik. Dengan mereka diam dan menyimak, artinya mereka serius merenungkan setiap permasalahan pada subjek yang sedang dibahas. Lagipula di Jepang terdapat filosofi 'mereka yang banyak tahu tidak berbicara, dan yang tidak tahu apa-apa banyak berbicara'.

Dua peristiwa tersebut menunjukkan sangat pentingnya untuk memahami dan mengenali perbedaan dari setiap budaya. Dengan memahami bahwa keanekaragaman budaya itu sangat luas dan mengagumkan, seseorang akan lebih terbuka menerima perbedaan yang ada dan membuka diri untuk mempelajari perbedaan yang ada. Konsep dan pemahaman tentang waktu, ruang, kehidupan setelah kematian, alam, dan realitas yang dimiliki masyarakat yang berlainan latar belakang budaya sedikit banyak akan berdampak pada proses dan keberhasilan dalam berkomunikasi dan berbisnis internasional.

Berbagai penelitian tentang kesadaran antarbudaya (intercultural awareness) dan (intercultural sensitivity) telah banyak dilakukan oleh para akademisi komunikasi antarbudaya. Terbukti bahwa kepekaan antarbudaya yang tinggi dan sikap positif terhadap multikulturalisme secara signifikan akan menurunkan etnosentrisme; yang selanjutnya akan mengurangi konflik antarbudaya dan antarkelompok (Dong, Day, \& Collaço, 2008).

\title{
Mengenali Budaya Lain
}

Budaya didefinisikan sebagai kumpulan pengetahuan, pengalaman, keyakinan/kepercayaan, nilai-nilai, sikap, makna, hierarki, agama, konsepsi waktu, peran, jarak, hubungan, konsep-konsep umum, objek material dan milik dari sekelompok orang yang diturunkan dari generasi ke generasi melalui individu dan kelompok (Samovar, Porter, \& McDaniel, 2010). Selanjutnya, Samovar, Porter dan McDaniel (2010) menyatakan, agar budaya dapat diturunkan dari satu generasi ke generasi berikutnya, individu dan kelompok budaya harus mengomunikasikan setiap aspek dari budaya. Oleh karena itu, budaya dan komunikasi tidak dapat dipisahkan dan menjalin suatu ikatan yang kuat. Budaya menentukan bagaimana cara berbicara, apa yang dibicarakan, kepada siapa pesan disampaikan, dalam kondisi yang bagaimana pesan disampaikan dan diterima, dan bagaimana pesan 
diinterpretasikan. Budaya sebagai dasar untuk berkomunikasi, dan ketika budaya beraneka ragam, cara berkomunikasi pun beraneka ragam.

Pakar budaya mengklasifikasikan budaya-budaya dari berbagai bangsa/negara. Pakar-pakar tersebut antara lain Gudykunts dan Kim, Hall dan Hall, dan Hofstede. Klasifikasi yang dibuat oleh Hall (1984), Hall dan Hall (1990; 1990) masih relevan dan selalu dikutip oleh pakar-pakar komunikasi antarbudaya lainnya sampai saat ini. Ia menjelaskan dan mengklasifikasi budaya di dunia berdasarkan konsep waktu dan konteks budaya. Gudykunts dan Kim (2003) membuat klasifikasi individualistic dan collectivistic culture. Sedangkan Hofstede (2005) mengidentifikasi dimensi nilai dan mengukur derajat dimensi nilai tersebut pada lebih dari 50 negara di seluruh dunia.

Hall dan Hall (1990) mengategorikan berbagai kebudayaan mulai dari low-context cultures (LCC) sampai pada high-context culture (HCC). Pada high-context culture sebagian besar informasi dituangkan dalam konteks fisik atau diinternalisasikan di dalam orang-orang yang berinteraksi. Sangat sedikit informasi berupa pesan-pesan verbal dan lebih ahli dalam membaca lingkungan dan perilaku nonverbal. Orang-orang high-context culture mengharapkan orang lain dapat memahami komunikasi nonverbal mereka. Jepang, Cina, Indonesia, dan negara-negara Asia lainnya merupakan high-context culture.

"Perception gap" yang terjadi pada kisah Yoshida disebabkan delegasi Jepang berasal dari HCC yang mengharapkan delegasi Amerika dapat memahami pesan nonverbal 'dingin' dan 'bungkam' sebagai bentuk penghargaan terhadap pendapat dan pemikiran delegasi Amerika. Sedangkan delegasi Amerika berasal dari LCC. Pada low-context culture sebagian besar informasi berupa pesan-pesan verbal. Pesan verbal sangat penting karena masyarakat LCC cenderung tidak belajar bagaimana memperoleh informasi dari lingkungan. Ketidaksetujuan dan perbedaan pendapat harus diungkapkan secara verbal karena masyarakat LCC sulit untuk memahami pesan nonverbal. Amerika Serikat, Australia, dan negara-negara Eropa Barat lainnya adalah low-context culture.

Selain mengategorikan berbagai budaya menjadi LCC dan HCC, Hall dan Hall $(1984,1990)$ mengategorikan waktu menjadi monochronic time (M-time) dan polychronic time (P-time). Hall mencirikan orang-orang monochronic time dan polychromic time. Namun demikian, mereka meminta pencirian ini jangan diaplikasikan ke semua budaya, hanya untuk menolong menemukan pola.

Ciri orang M-time antara lain: berasal dari LCC, melakukan satu hal pada satu waktu dan sangat berkonsentrasi pada satu pekerjaan, menggunakan waktu berdasarkan komitmen (jadwal, deadline), membutuhkan informasi yang lengkap dan mendetail, terikat pada pekerjaan, ketat mengikuti rencana, sangat menghargai privacy. Sedangkan orang-orang $P$-time bercirikan: berasal dari HCC, melakukan berbagai hal pada satu waktu sehingga hal dilakukan sering kali terinterupsi, terikat pada orang dan hubungan antarmanusia, mudah dan sering kali berubah rencana, memiliki hubungan erat dengan keluarga dan teman.

Gudykunts dan Kim (2003) menyatakan bahwa negara-negara di Asia dan Amerika Selatan termasuk budaya kolektif. Budaya kolektif menitikberatkan kebersamaan dan ikatan keluarga dan kelompok sangat penting. Sedangkan negara-negara di Eropa Barat dan Amerika Utara, masyarakatnya termasuk budaya indivialistis.

Hofstede dan Hofstede (2005) melakukan survei pada karyawan IBM di semua perwakilannya di 74 negara untuk mengidentifikasi perbedaan sistem nilai di setiap negara (national values). Nilainilai yang diukur meliputi 4 dimensi. Pertama, power distance, berhubungan dengan social inequality termasuk hubungan dengan otoritas. Derajat yang dinilai dari kecil sampai besar. Makin tinggi skor sebuah negara, makin besar jarak kekuasaan di masyarakatnya. Kedua, collectivism versus individualism, berhubungan dengan konsep diri, hubungan yang terjalin antarindividu dan individu dengan kelompok/masyarakat. Makin tinggi skor sebuah negara, makin individualistis masyarakat 
negara tersebut. Ketiga, femininity versus masculinity, implikasi sosial dan emosional terlahir sebagai laki-laki atau perempuan. Makin tinggi skor sebuah negara, makin maskulin masyarakat negara tersebut. Keempat, uncertainty avoidance, cara-cara menghadapi ketidakpastian dan ambiguitas yang terwujud pada ekspresi emosi dan kontrol terhadap agresi. Derajat yang dinilai dari lemah sampai kuat. Makin tinggi skor sebuah negara, makin tinggi tingkat kecemasan dan makin tidak bisa menerima ketidakpastian.

Tabel 1 menunjukkan empat dimensi nilai hasil penelitian Hofstede. Dari 74 negara yang diteliti Hofstede, penulis hanya memilih negara yang warga negaranya paling banyak bekerja di Indonesia dan negara yang banyak warga negara Indonesia bekerja dan tinggal di sana. Negara yang menunjukkan skor power distance yang tinggi, seperti Malaysia, jarak status dan kekuasaan atasan dan bawahan tinggi. Kekuasaan tersentralisasi dan dipegang oleh sedikit orang dengan struktur piramida hierarki yang tinggi. Bawahan harus selalu patuh pada perintah atasan dan atasan sangat dihormati. Atasan memperoleh berbagai fasilitas dan keistimewaan serta terdapat perbedaan gaji yang tinggi antara atasan bawahan. Sebaliknya, negara yang menunjukkan skor power distance yang rendah, seperti Jerman, hubungan atasan bawahan cenderung sederajat, sistem hierarki hanya untuk perbedaan peran/tugas. Organisasi cenderung desentralisasi dengan struktur piramida hierarki yang pendek. Atasan yang dihormati adalah atasan yang demokratis.

Masyarakat di negara yang menunjukkan skor tinggi pada dimensi individualistic menunjukkan karakteristik masyarakat low-context culture, berorientasi dan berpikir "saya" bukan "kami", independen, menjunjung tinggi privacy dan kepemilikan individu, media sebagai sumber informasi utama, berkepribadian lebih ekstrover dan didukung untuk mengekspresikan perasaan dan pikiran. Sebaliknya, masyarakat di negara collectivistic sangat berorientasi "kami", sangat tergantung pada keluarga besar dan kelompoknya, harmoni diutamakan dan menghindari konfrontasi langsung, berbagi dengan keluarga atas sumber daya yang dimiliki, high-context culture, sangat menjaga nama baik keluarga dan kelompok, jaringan sosial adalah sumber informasi utama dan terpercaya, berkepribadian cenderung introver.

Tabel 1 Dimensi Nilai Hofstede pada Beberapa Negara

\begin{tabular}{|c|c|c|c|c|c|c|c|}
\hline \multicolumn{8}{|c|}{ Dimensi Nilai } \\
\hline \multicolumn{2}{|c|}{ Power Distance } & \multicolumn{2}{|c|}{ Individualism } & \multicolumn{2}{|c|}{ Masculinity } & \multicolumn{2}{|c|}{$\begin{array}{c}\text { Uncertainty Avoidance } \\
\text { and Anxiety }\end{array}$} \\
\hline Negara & Skor & Negara & Skor & Negara & Skor & Negara & Skor \\
\hline Malaysia & 104 & USA & 91 & Jepang & 95 & Jepang & 92 \\
\hline Cina & 80 & Australia & 90 & Cina & 66 & Perancis & 86 \\
\hline Arab & 80 & Inggris & 89 & Jerman & 66 & Korsel & 85 \\
\hline Indonesia & 78 & Belanda & 80 & Inggris & 66 & Arab & 68 \\
\hline India & 77 & Perancis & 71 & USA & 62 & Jerman & 65 \\
\hline Singapura & 74 & Jerman & 67 & Arab & 61 & Belanda & 53 \\
\hline Perancis & 68 & India & 48 & India & 56 & Australia & 51 \\
\hline Korsel & 60 & Jepang & 46 & Arab & 53 & Indonesia & 48 \\
\hline Jepang & 54 & Arab & 38 & Malaysia & 50 & USA & 46 \\
\hline USA & 40 & Malaysia & 26 & Singapura & 48 & India & 40 \\
\hline Belanda & 38 & Cina & 20 & Indonesia & 46 & Malaysia & 36 \\
\hline Australia & 36 & Singapura & 20 & Perancis & 43 & Inggris & 35 \\
\hline Inggris & 35 & Korsel & 18 & Korsel & 39 & Cina & 30 \\
\hline Jerman & 35 & Indonesia & 14 & Belanda & 14 & Singapura & 8 \\
\hline
\end{tabular}

Sumber: (Hofstede \& Hofstede, 2005) 
Negara yang menunjukkan skor tinggi pada dimensi masculinity, masyarakatnya cenderung untuk mempertahankan standar yang berbeda antara laki-laki dan perempuan: laki-laki adalah subjek dan perempuan adalah objek. Meniti karier adalah kewajiban untuk laki-laki dan pilihan untuk perempuan serta kesempatan yang lebih sedikit untuk perempuan pada pekerjaan profesional. Masyarkat lebih senang pada organisasi yang besar dan kompetitif. Penyelesaian konflik lebih pada yang kuat yang menang. Pilihan pekerjaan berdasarkan kesempatan berkarier yang tinggi. Sedangkan pada negara yang menunjukkan skor rendah pada dimensi masculinity, pilihan pekerjaan berdasarkan minat individu, organisasi cenderung lebih kecil, dan penyelesaian konflik melalui negosiasi dan kompromi. Karier adalah pilihan untuk laki-laki dan perempuan.

Dimensi selanjutnya berhubungan dengan kecemasan (anxiety). Kecemasan diartikan sebagai perasaan tidak nyaman atau khawatir terhadap hal yang mungkin terjadi. Tingginya angka bunuh diri di suatu negara dapat dijadikan ukuran tingkat kecemasan masyarakatnya. Uncertainty avoidance merujuk pada upaya untuk mengurangi kedwiartian (ambiguity), segala sesuatu yang tidak pasti, dan mencari yang bisa diprediksi dan secara jelas dapat diinterpretasi. Pada konteks perusahaan dan organisasi negara yang memiliki skor uncertainty avoidance tinggi memiliki karakteristik seperti: waktu adalah uang, rendahnya toleransi terhadap ketidakjelasan dan kekacauan dan segala sesuatunya harus presisi dan formal, manajer lini atas sangat memerhatikan kegiatan operasional sehari-hari, sangat baik pada implementasi namun buruk pada inovasi. Sedangkan pada organisasi dengan skor uncertainty avoidance rendah, manajer lini atas dan pimpinan lebih memerhatikan strategi. Mereka sangat baik pada inovasi/ide-ide baru namun buruk pada implementasi. Waktu sebagai kerangka orientasi dalam bekerja. Toleransi tinggi terhadap ketidakpastian dan kekacauan.

Sebaiknya, tidak hanya terpaku pada klasifikasi yang dibuat para pakar/peneliti. Untuk meningkatkan pemahaman dan kesadaran antarbudaya, sebaiknya seorang juga memerhatikan perbedaan-perbedaan dan keunikan-keunikan yang ada pada setiap budaya, terutama budaya yang masyakaratnya akan berinteraksi dengan orang tersebut. Harus dikembangkan bahwa setiap budaya itu unik dan seorang harus open minded bahwa tidak ada budaya yang paling benar dan paling beradab.

\section{Tantangan Berkomunikasi Antarbudaya pada Dunia Kerja Global}

Berkomunikasi dengan orang yang berbeda latar belakang budaya bukanlah hal yang mudah. Organisasi dan individu yang ingin dapat bersaing di ranah global harus mempersiapkan diri menghadapi tantangan dan berbagai kesulitan yang akan dialami ketika menjalin bisnis, bernegosiasi, atau bekerja di perusahaan global. Sebagai individu global harus mempersiapkan diri agar bisa sukses dan efektif berkomunikasi dengan orang yang berbeda latar belakang budaya. Ketika seorang berkomunikasi dengan orang-orang yang berbeda latar belakang budaya, saat itulah orang itu sedang berkomunikasi antarbudaya.

Globalisasi membuat karyawan di berbagai perusahaan dan organisasi makin heterogen, juga menuntut organisasi harus memahami perbedaan regulasi, situasi sosial politik, kondisi ekonomi dan lingkungan sosial berbagai negara. Setiap organisasi global atau yang sedang mempersiapkan diri untuk menjadi organisasi global, harus mempersiapkan setiap anggotanya dapat berkomunikasi antarbudaya dengan efektif karena keterampilan berkomunikasi antarbudaya adalah tulang punggung untuk mendukung transaksi bisnis di seluruh dunia (Chitakornkijsil, 2010; Patrick \& Kumar, 2012). Persiapan diri ini tidak hanya untuk individu yang ingin tinggal dan bekerja di luar negeri atau perusahaan yang ingin mengembangkan bisnisnya ke negara lain, tetapi juga bagi para eksportir dan importir. Perbedaan kebiasaan, perilaku, nilai-nilai dapat menjadi masalah dan hanya dapat diselesaikan melalui interaksi dan komunikasi antarbudaya yang efektif (Samovar, Porter dan McDaniel, 2010). Dan salah satu masalah utama yang sering menghalangi komunikasi antarbudaya adalah diskriminasi yang diikuti dengan prasangka dan etnosentrisme (Patrick \& Kumar, 2012). 
Bagi para manajer global, mampu berkomunikasi dengan efektif adalah keterampilan yang sangat penting karena kelancaran perencanaan, pengorganisasian, memonitor, dan memfasilitasi semuanya dapat terlaksana dengan baik melalui komunikasi. Ketika semua aktivitas manajerial itu harus dilakukan bersama-sama dengan orang-orang yang berbeda latar belakang budaya, menurut Chitakornkijsil (2010), hal yang paling sulit adalah proses encoding dan decoding pesan agar makna dapat diinterpretasikan dengan tepat. Walaupun pesan verbal adalah adalah cara utama dalam menyandi pesan, pesan-pesan nonverbal seperti nada suara, ekspresi wajah, postur tubuh, bahasa tubuh, jarak, dan kontak mata mengandung makna yang lebih luas dan kompleks. Justru pesan-pesan nonverbal ini yang sering kali ambigu dan dapat menimbulkan kesalahpahaman.

Selain masalah dalam encoding dan decoding pesan, hambatan utama bagi para manajer global adalah beranekaragamnya bahasa. Kurang lebih 6000 bahasa digunakan di seluruh dunia (Chitakornkijsil, 2010) dengan 10.000 dialek (Saee, 2007). Seorang manajer global harus menguasai lebih dari 1 bahasa dan minimal menguasai bahasa Inggris sebagai bahasa internasional. Walaupun kedua pihak yang berkomunikasi sama-sama menguasai bahasa Inggris, masih kerap terjadi kesalahpahaman. Chitakonrkijsil (2010) menyarankan, para manajer global sebaiknya menguasai bahasa konsumennya dan bahasa lokal tempat ia bekerja.

Tantangan lain yang kerap dialami para manajer global dan pengusaha adalah terbatasnya waktu untuk mengenal lebih dekat bahasa dan budaya dari klien, konsumen, dan rekan bisnis. Waktu penempatan yang singkat di suatu negara dan ketatnya jadwal perjalanan bisnis sering kali membuat para manajer global dan pengusaha tidak dapat menindaklanjuti pesan-pesan mereka dan mendorong adanya umpan balik (feedback) dari rekan bisnis dan dari para pemangku kepentingan dari berbagai latar belakang budaya (Chitakonrkijsil, 2010).

Berdasarkan pengalamannya, Yoshida (2002) selanjutnya menambahkan 4 masalah utama yang ia temui selama menjadi CEO global, yaitu: 1) kurangnya kemampuan berbahasa Inggris yang mumpuni, lisan dan tulisan para karyawan dan manajer. Kemampuan dan keterampilan berbahasa Inggris yang tidak cukup akan menyebabkan keterlambatan dalam merespons instruksi sehingga memengaruhi proses bisnis dan kelancaran operasional. 2) Para manajer dan pimpinan perusahaan global di kantor pusat sering kali kurang berkomunikasi dengan para manajer di kantor cabang tentang visi dan kebijakan-kebijakan strategis perusahaan. Hal ini dapat menghilangkan kesempatan untuk mempelajari perbedaan-perbedaan strategis dan melakukan brainstorming dengan para manajer lokal untuk mengatasi masalah lokal. 3) Keangkuhan budaya dan etnosentrisme dari para pimpinan dan manajer global yang menghambat pemahaman antarbudaya. 4) Kurangnya pengetahuan dan pemahaman kebutuhan lokal serta penyesuaian tata laksana aturan yang sesuai dengan norma dan nilai-nilai budaya setempat, termasuk memahami perbedaan persepsi dan gaya berkomunikasi.

Selanjutnya penulis sempat melakukan wawancara singkat dengan seorang manajer government relations perusahaan multinasional di Jakarta tentang masalah yang dihadapi dalam berkomunikasi antarbudaya. Ia menyatakan bahwa sering kali pimpinan dari kantor pusat yang sebagian besar berasal dari Eropa dan Amerika Serikat mendesak agar negosiasi dengan pejabat pemerintah cepat membawa hasil dan ketika menyampaikan pesan-pesan serta membahas issue perusahaan ia diminta untuk to-the-point. Ketika turut serta dalam pertemuan-pertemuan dengan pejabat pembuat keputusan sering kali pimpinan dari kantor pusat tidak sabar mengikuti pembicaraanpembicaraan ringan sebelum membahas issue yang dibawa. Hal ini acap kali membuat manajer serba salah dan bingung harus berbuat apa untuk mengakomodasi permintaan atasan namun harus tetap menjaga hubungan baik dan perasaan pejabat. Karena ia tahu, jika ia bersikap terlalu mendesak, bisa jadi hasil negosiasi yang selama ini telah tercapai akan percuma.

Dari kisah manajer tersebut, terlihat kurangnya pemahaman antarbudaya dan adanya benturan budaya antara pimpinan dari kantor pusat dengan manajer lokal. Pimpinan dari kantor pusat berasal dari budaya low-context culture dan monochronic-time yang perbedaan pendapat dan semua ide 
diungkapkan secara verbal dan to-the-point serta mereka sangat berorientasi pada waktu/jadwal. Sedangkan pejabat Indonesia berasal dari budaya high-context culture dan polychronic-time yang lebih mengutamakan hubungan yang nyaman tanpa terlalu terpaku dengan waktu ketika menjalani proses untuk mencapai hubungan yang baik tersebut. Kondisi ini tentunya menjadi tantangan untuk para manajer lokal yang bekerja di perusahaan multinasional untuk dapat memahami perbedaan yang ada dan bagaimana cara mereka menghadapinya dengan baik.

Studi tentang ekspatriat menunjukkan penugasan internasional menghasilkan biaya tinggi, masalah adaptasi individu dan keluarga, kinerja yang buruk, kesulitan mempertahankan produktivitas dan hubungan yang memuaskan dengan orang-orang di negara tuan rumah. Kondisi tersebut ternyata bukan disebabkan tidak cakapnya secara teknis manajerial tetapi lebih pada dinamika pengalaman antarbudaya yang dihadapi (Saee, 2007).

Selanjutnya Saee (2007) menyatakan sebagian besar perusahaan multinasional menganggap bahwa memberikan pelatihan bahasa Inggris untuk manajer dan karyawannya sudah cukup. Para pimpinan perusahaan berasumsi bahwa untuk komunikasi antarbudaya yang efektif hanyalah masalah kompetensi linguistik dan berkomunikasi itu seperti keterampilan mekanik yang tidak melibatkan emosi dan berbagai faktor antarpribadi. Padahal memiliki kompetensi berbahasa asing baru menyelesaikan sebagian masalah.

Seorang manajer global yang fasih berbahasa Inggris namun enggan belajar bahasa lokal akan kehilangan nuansa dan potongan makna dari sebuah percakapan. Banyak informasi penting dari orang lokal yang sangat membantu menyelesaikan masalah perusahaan dan memperoleh gambaran yang utuh tentang hal yang terjadi. Bahkan seorang manajer Inggris yang bekerja di Jerman pun patut belajar bahasa Jerman meskipun banyak orang Jerman mampu berbahasa Inggris dan Inggris-Jerman sama-sama low-context culture (Beamer dan Varner, 2008).

Pet-kevičiūtė and Budaitė (dalam Pliopaitė \& Radzevičienè, 2010) mengidentifikasi masalah-masalah yang sering timbul dalam organisasi multikultural, yaitu: perbedaan watak dari para komunikator, perbedaan gaya dan cara bernegosiasi, perbedaan persepsi tentang hubungan atasanbawahan, perbedaan pola pengelolaan waktu, perbedaan budaya kerja dan aturan berperilaku, serta perbedaan gaya pengambilan keputusan. Dari berbagai tantangan yang ada dan telah dijabarkan, sebenarnya tantangan terbesar justru berasal dari dalam diri para komunikator antarbudaya. Persepsi dan sikap yang dapat menghambat bahkan berpotensi menggagalkan komunikasi harus dihilangkan. Berbagai penelitian telah membuktikan bahwa sikap etnosentrisme, ketidakpercayaan, kurangnya empati, penghindaran, apatis, stereotyping, dan prasangka potensial menggagalkan komunikasi bahkan dapat menimbulkan konflik (Pliopaitè \& Radzevičienè, 2010).

\section{Menjadi Kompeten}

Kompetensi diterjemahkan sebagai kecakapan atau kemampuan. Berbagai literatur menempatkan kompetensi komunikasi antarbudaya hampir sama dengan kompetensi komunikasi secara umum. Orang yang kompeten dalam berkomunikasi artinya ia dapat berkomunikasi dengan efektif, yakni pesan dimaknai sama oleh pengirim dan penerima pesan. Jadi, kompetensi komunikasi antarbudaya melihat keberhasilan dan kelayakan komunikasi dan interaksi antara orang-orang dari budaya yang berbeda yang mengidentifikasikan lingkungan simbolik dan fisik tertentu (Mulyana, 2005; Deardorff, 2006).

Para ilmuwan komunikasi antarbudaya mengidentifikasi empat komponen dasar dari kompetensi komunikasi antarbudaya, yaitu: motivasi, pengetahuan, sikap, dan perilaku (Wiseman dalam Martin \& Nakayama, 2007). Setiap ilmuwan menjabarkan 4 komponen tersebut ke penjelasan yang lebih mendetail. Hofstede (2001) menyatakan bahwa untuk dapat mahir berkomunikasi antarbudaya harus melalui tahapan awareness, knowledge, dan skills. 
Martin dan Nakayama (2007) menjabarkan kompetensi komunikasi antarbudaya menjadi 2 komponen, yaitu komponen individual dan komponen kontekstual. Komponen individual terdiri dari 1) motivasi, yaitu keinginan untuk berkomitmen dalam hubungan, keinginan untuk belajar tentang diri pribadi dan orang lain, dan berusaha untuk fleksibel; motivasi adalah dimensi terpenting dalam komponen individual; 2) pengetahuan dan pengetahuan tentang diri sendiri, yaitu mengenal kelebihan dan kekurangan diri sebagai komunikator; 3) pengetahuan bahasa, yaitu pengetahuan tentang bahasa ibu, bahasa asing, dan tahu kesulitan-kesulitannya; 4) sikap, termasuk toleran terhadap makna ambigu, empati, dan tidak berprasangka buruk; 5) perilaku dan keterampilan. Komponen kontekstual terdiri dari 1) pemahaman atas konteks dan setting komunikasi berlangsung, karena seorang komunikator yang baik harus sensitif pada kondisi dan latar budaya sekelilingnya dan 2) mengetahui posisi sebagai komunikator di dalam suatu percakapan/pertemuan/situasi.

Chen dan Starosta (2008) menawarkan sebuah model kompetensi komunikasi antarbudaya. Model ini bertujuan untuk meningkat kemampuan interaktan dalam memahami, menghargai, mentoleransi, dan mengintegrasikan perbedaan budaya, sehingga mereka siap menjadi menjadi anggota masyarakat dunia. Model ini menyajikan sebuah proses transformasional dari saling ketergantungan simetris yang dijelaskan melalui tiga perspektif: (a) affective atau sensitivitas antarbudaya; (b) cognitive atau kesadaran antarbudaya; dan (c) behavioral atau kecakapan antarbudaya.

Ketiga perspektif ini sama-sama penting, tidak dapat dipisahkan dan membentuk gambaran yang holistis dari kompetensi komunikasi antarbudaya. 1) The affective process: intercultural sensitivy, meliputi self-concept (konsep diri) adalah cara seseorang memandang dirinya, openmindedness (berpikiran terbuka), non-judmental attitudes yaitu tidak berprasangka buruk, dan social relaxation adalah kemampuan untuk mengungkap hanya sedikit kecemasan emosi ketika berkomunikasi antarbudaya. 2) The cognitive process: intercultural awareness, meliputi selfawareness atau self-monitoring (kesadaran diri) dan cultural awareness (kesadaran budaya). 3) The Behavioral Process: Intercultural Adroitness (Communication Skills), meliputi message skills yaitu kemampuan untuk menggunakan bahasa orang lain, appropriate self-disclosure adalah pengungkapan diri yang layak, behavioral flexibility adalah kemampuan untuk memilih perilaku yang layak dalam konteks dan situasi yang berbeda, interaction management merupakan kemampuan untuk berbicara dalam percakapan dan untuk memulai dan menghentikan pembicaraan secara layak, dan social skills (empati).

Kim (dalam Gudykunts dan Kim, 2003) mengemukakan 3 dimensi kompetensi komunikasi antarbudaya terutama untuk expatriate yang ditempatkan di suatu negara. Pertama, dimensi kognitif memiliki pengetahuan tentang bahasa setempat, tanda-tanda nonverbal, nilai-nilai budaya, sistem komunikasi dan aturan berinteraksi. Kedua, dimensi afektif memiliki motivasi dan orientasi sikap yang sesuai dengan budaya setempat, memiliki sensitivitas budaya, rasa humor, dan lain-lain. Ketiga, dimensi perilaku memiliki kemampuan berbicara, mendengarkan, membaca dan menulis bahasa setempat, mampu mengekspresikan dan memahami ekspresi nonverbal, dapat mengikuti aturan berinteraksi dan mampu mengelola hubungan.

Berbagai komponen dan dimensi kompetensi komunikasi antarbudaya yang telah dikemukakan beberapa ilmuwan tersebut sebaiknya ditambah dengan aspek-aspek penting yang patut diketahui dan dipahami dalam konteks bisnis multikultural dan dunia kerja global. Para pengusaha dan manajer global, sepatutnya memberi perhatian dan siap menghadapi perbedaan-perbedaan pada: business protocol, seperti aturan pada pertemuan pertama, sikap dan perilaku ketika menyambut rekan bisnis, penampilan personal, aturan pemberian hadiah, hal-hal tabu dalam percakapan; gaya kepemimpinan; gaya dan cara pengambilan keputusan; etika bisnis dan negosiasi, termasuk masalah formalitas dan status, kecepatan dan kesabaran dalam bernegosiasi, ekspresi emosi, pesan langsung dan tidak langsung, pemahaman antara bukti dan kebenaran (Samovar, Porter \& McDaniel, 2009). 
Upaya untuk meningkatkan kompetensi komunikasi antarbudaya tidak bisa hanya ditujukan kepada para karyawan yang akan dikirim untuk penugasan internasional dan para ekspatriat yang ditempatkan tetapi juga kepada seluruh karyawan juga harus dikelola kemampuannya dalam berinteraksi dan berelasi antarbudaya. Keterampilan yang dimiliki seluruh karyawan dalam berinteraksi antarpribadi dan antarbudaya sangat penting untuk kesuksesan manajemen global (Graf \& Harland, 2005).

Selanjutnya, Graf dan Harland (2005) menganjurkan setiap organisasi global atau organisasi yang bervisi global melakukan pengukuran kompetensi antarpribadi dan kompetensi antarbudaya bagi seluruh karyawannya. Pengukuran ini tentunya sangat bermanfaat disaat menyeleksi calon-calon ekspatriat. Penelitian Graf dan Harland membuktikan bahwa karyawan yang memiliki kompetensi antarpribadi dan antarbudaya akan mampu menghadapi masalah sosial, masalah antarpribadi, mampu menghadapi tantangan-tantangan dalam mengelola perbedaan budaya, dan memiliki keinginan untuk berinteraksi dengan orang-orang yang berlatar belakang budaya berbeda.

Perusahaan-perusahaan Korea, Prancis, Jerman dan Jepang mengharapkan karyawannya mampu cepat beradaptasi, mampu berfungsi dan berkomunikasi dengan cakap dalam berbagai konteks budaya. Perusahaan-perusahaan Eropa mengharapkan para manajernya menguasai minimal satu bahasa asing dengan baik. Semua ilmuwan komunikasi antarbudaya sepakat bahwa keahlian teknis tidaklah cukup, karyawan dan manajer harus mampu beradaptasi pada berbagai konteks budaya, sensitivitas dan berkemampuan bahasa Inggris dan lokal adalah hal penting (Chitakornkijsil, 2010).

Strategi utama yang sebaiknya dilakukan organisasi untuk menumbuhkan dan meningkatkan sikap inklusi karyawannya adalah dengan diselenggarakannya pelatihan karyawan agar mereka peka terhadap perbedaan budaya, mendorong karyawan untuk menerima penugasan ke luar negeri, dan menawarkan pelatihan bahasa asing. Selanjutnya, organisasi harus mampu mengelola keanekaragaman yang ada dan memberdayakan segala potensi dari karyawannya sebagai keuntungan kompetitif (Patrick \& Kumar, 2012). Sementara saran untuk para pengusaha, pimpinan, manajer, dan karyawan global: 1) melakukan pelatihan komunikasi antarbudaya di dalam organisasi; mencoba melihat sesuatu dari sudut pandang (kultural) orang lain; 2) memulai dari diri sendiri membangun kompetensi komunikasi antarbudaya melalui evaluasi diri, menghapus prasangka budaya, meningkatkan sensitivitas dan pemahaman antarbudaya, membangun empati yang didasarkan pada penerimaan perbedaan dan pembentukan sikap positif; 3) melengkapi persenjataan agar mampu berempati, yaitu: kebijaksanaan, humor, kepekaan, keluwesan, kompromi, kehangatan, ketenangan, kesiapan utuk berdiskus, menyimak dengan hati-hati dan kesabaran; 4) mempelajari nilai budaya, adat kebiasaan, aturan dan ritual setempat/klien/rekan bisnis agar mampu bersikap dan berperilaku dengan layak dan tepat; 5) meningkatkan kualitas dan kuantitas komunikasi dengan klien, pimpinan, manajer, dan karyawan di kantor pusat dan di kantor cabang (Yoshida, 2002; Lewis, 2005).

\section{SIMPULAN}

Globalisasi melahirkan ribuan perusahaan internasional dan multinasional di seluruh dunia. Interaksi antara pekerja asing dan lokal tidak dapat dihindari, transaksi dan negosiasi bisnis tidak selalu sukses dan berjalan mulus. Kegagalan transaksi bisnis dan menurunnya kinerja perusahaan ternyata sering disebabkan perbedaan budaya. Untuk saat ini, bagi para pebisnis dan anggota organisasi multinasional, memahami budaya mitra asing adalah keharusan.

Menyadari, mengenal, dan memahami perbedaan-perbedaan budaya yang ada adalah hal terpenting. Setiap budaya memiliki keunikan dan karakteristik tersendiri; berbeda bahasa berarti berbeda budaya. Hapuslah prasangka, stereotyping, dan etnosentrism. Tingkatkan kepekaan budaya, 
bersikap terbuka terhadap perbedaan dan ketrampilan dalam berkomunikasi, serta berinteraksi dengan layak dan tepat.

Perusahaan lokal, multinasional, atau internasional harus segera melakukan pelatihan komunikasi antarbudaya, pelatihan kepekaan, dan pemahaman antarbudaya untuk semua karyawannya. Kompetensi komunikasi antarbudaya dapat tercapai melalui proses kepekaan antarbudaya, kesadaran antarbudaya, dan ketrampilan berkomunikasi antarbudaya. Perusahaan yang memiliki kompetensi antarbudaya akan mampu sukses dan mempertahankan kesuksesan dalam bisnis global.

\section{DAFTAR PUSTAKA}

Beamer, L., \& Varner, I. (2008). Intercultural Communication in The Global Workplace (4th Edition ed.). New York, USA: McGraw-Hill.

Chitakornkijsil, P. (2010). Intercultural Communication Challenges and Multinational Organization Communication. International Journal of Organizational Innovation, 6-20.

Dong, Q., Day, K., \& Collaço, C. (2008). Overcoming Ethnocentrism through Developing Intercultural Communication Sensitivity and Multiculturalism. Human Communication. A Publication of the Pacific and Asian Communication Association, 11(1), 27-38.

Graf, A., \& Harland, L. K. (2005). Expatriate Selection: Evaluating the Discriminant, Convergent, and Predictive Validity of Five Measures of Interpersonal and Intercultural Competence. Journal of Leadership \& Organizational Studies, 11(2), 1-18.

Gudykunts, W. B., \& Kim, Y. Y. (2003). Communicating with Strangers: An Approach to Intercultural Communication. New York: McGraw-Hill.

Gustaman, Y. (2012, 27 Desember). Alasan Diaspora Indonesia Dukung Dapil Khusus Luar Negeri. Diakses $\quad 27 \quad$ Februari 2013 dari http://www.tribunnews.com/nasional/2012/12/27/alasan-diaspora-indonesia-dukungdapil-khusus-luar-negeri

Hall, E. T. (1984). Dance of Life: The Other Dimension of Time. Anchor Books.

Hall, E. T., \& Hall, M. R. (1990). Hidden Differences: Doing Business with The Japanese. New York: Doubleday.

Hall, E. T., \& Hall, M. R. (1990). Understanding Cultural Differences. Maine, USA: Intercultural Press.

Hofstede, G. H. (2001). Culture's Consequence. Comparing Values, Behaviours, Institutions, and Organizations Across Nations (2nd Edition ed.). California, USA: Sage.

Hofstede, G., \& Hofstede, G. J. (2005). Cultures and Organizations. Software of the Mind. Intercultural Cooperation and Its Importance for Survival (2nd Edition ed.). New York: McGraw-Hill. 
Kementerian Tenaga Kerja dan Transmigrasi Republik Indonesia. (2013). Diakses 27 Februari 2013 dari http://pusdatinaker.balitfo.depnakertrans.go.id/

Kompas. (n.d.). Diakses 27 Februari 2013 dari www.kompas.com.

Lewis, R. D. (2005). Komunikasi Bisnis Lintas Budaya (2nd Edition ed.). (D. Mulyana, Trans.) Bandung: Remaja Rosdakarya.

Martin, J. N., \& Nakayama, T. K. (2007). Intercultural Communication in Contexts (4th Edition ed.). Boston, USA: McGraw-Hill.

Mitchell, C. (2008). A Short Course in International Business Culture: Building Your International Business Through Cultural Awareness. (E. M. Nusron, Trans.) California: World Trade Press.

Mulyana, D. (2005). Komunikasi Efektif. Suatu Pendekatan Lintasbudaya (2nd Edition ed.). Bandung: Remaja Rosdakarya.

Patrick, H. A., \& Kumar, V. R. (2012). Managing Workplace Diversity: Issues and Challenges. SAGE Open (April-June), 1-16.

Pliopaite, I., \& Radzevičienè, A. (2010). Intercultural Competence Development in EU Banking Sector. Journal Business in XXI Century, 75-82.

Saee, J. (2007). Intercultural Awareness is the Key to International Business Success. Global Focus Proquest Entrepreneurship, 1(3).

Samovar, L. A., Porter, R. E., \& McDaniel, E. R. (2010). Communication Between Cultures (7th Edition ed.). Boston, USA: Wadsworth Cengage Learning.

Yoshida, S. (2002). Globalization and issues of intercultural communications: Doing successful business in Asia. ProQuest Research Library, 708. 